\title{
PERANCANGAN INVERTER BERBASIS MIKROKONTROLER DSPIC30F4011 DENGAN FEEDBACK TEGANGAN MENGGUNANKAN METODE KONTROL PROPORTIONAL INTEGRAL
}

\author{
Eri Sudantoko*), Iwan Setiawan. dan Mochammad Facta \\ Departemen Teknik Elektro, Universitas Diponegoro \\ Jl. Prof. Sudharto, SH, Kampus UNDIP Tembalang, Semarang 50275, Indonesia \\ ${ }^{*}$ E-maerisudantoko@gmail.com
}

\begin{abstract}
Abstrak
Sumber energi tenaga matahari merupakan salah satu sumber energi terbarukan yang mudah untuk didapatkan. Sel Surya energi matahari dapat dikonversi menjadi energi listrik tegangan arus searah, sehingga dapat digunakan sebagai sumber energi peralatan listrik. Namun demikian, saat ini sebagian besar peralatan listrik menggunakan sumber tegangan arus bolak balik, sehingga diperlukan sebuah konverter dengan masukan tegangan arus searah untuk diubah menjadi keluaran tegangan arus bolak balik. Peralatan tersebut biasa disebut inverter. Beban inverter yang berupa peralatan listrik pada umumnya memiliki karakteristik jenis beban bermacam-macam. Jenis - jenis beban ini dapat mengakibatkan inverter dapat mengalami tegangan jatuh sehingga peralatan listrik kurang bekerja sesuai unjuk kerjanya. Dalam Penelitian ini, inverter satu fasa tipe jembatan penuh dengan umpan balik tegangan dirancang menggunakan metode kontrol proportional integral yang diproses menggunakan mikrokontroler dsPIC30F4011. Gelombang tegangan keluaran inverter disensor oleh sensor tegangan. Sinyal analog umpan balik dikoversikan ke bentuk digital oleh suatu konverter analog ke digital sebagai input mikrokontroller. Mikrokontroller yang memuat algoritma kontrol proporsional integral menghasilkan sinyal kontrol yang membuat tegangan keluaran inverter dapat mengikuti nilai yang ditentukan.
\end{abstract}

Kata kunci : Inverter, Kontrol Tegangan, Proportional Integral, dsPIC30F4011..

\begin{abstract}
Solar energy source is one of renewable energy source which is easy to get. Solar energy can be converted easily into direct current electrical energy, so it can be used as an energy source of electrical equipment. However, nowadays most of electrical equipment use alternating current, so they need a converter to convert direct current input into alternating current output. The converter is commonly called inverter. Inverter loads have various types of characteristics. These types of loads leads to a condition where the inverter can get a drop voltage causing electrical equipment have low performance. In this work, full bridge one phase inverter with voltage feedback is designed by using proportional integral control method processed by dsPIC30F4011 microcontroller. The output voltage of the inverter is sensed by voltage sensor. The feedback signal in analog form sent by voltage sensor is converted by analog to digital converter to digital input of microcontroller. Microcontroller containing algorithm of proportional integral control produce the control signal to make output voltage of inverter can follow the desired setting value.
\end{abstract}

Keywords : Inverter, Voltage Control, Proportional Integral, dsPIC30F4011.

\section{Pendahuluan}

Peningkatan konsumsi jumlah energi global yang semakin cepat membutuhkan sumber greener energy. Oleh karena itu, energi terbarukan yang berkelanjutan dan tak habis dari angin, photovoltaic, atau pasang surut air laut banyak diteliti. Distributed power generation systems (DPGS) cukup menarik dalam hal penjualan dan peneliti, dan yang paling penting dalam DPGS adalah inverter yang terkoneksi dengan grid menjadi pusat penilitian [1] Inverter satu fasa adalah converter yang mengubah sistem listrik DC menjadi AC. Keluaran inverter satu fasa adalah tegangan keluaran $\left(\mathrm{V}_{\mathrm{O}}\right)$ dan arus ouput $\left(\mathrm{I}_{\mathrm{O}}\right)$. Dalam penelitian ini telah dirancang inverter satu fasa yang mengubah sistem listrik DC menjadi AC. Dari sekian metode pemicuan Pulse Width Modulation (PWM), dipilih metode pemicuan Sinusoidal Pulse Width Modulation (SPWM) untuk menghasilkan sinyal referensi sinusoidal yang presisi [2].

Pada Penelitian ini dirancang inverter satu fasa dengan sistem kendali mikrokontroler dsPIC30F4011. Pembangkitan sinyal SPWM menggunakan 
dsPIC30F4011 lebih mudah dan ringkas karena mikrokontroler ini sudah langsung memiliki keluaran 6 output PWM, dan pembangkitan sinyalnya dilakukan melalui senarai program. Selain itu dsPIC30F4011 memiliki kemampuan Digital Signal Processing [3] yang mampu memproses data secara cepat dan mempunyai lebar data 16 bit [4].

Pada inverter yang dibuat pada Penelitian ini diharapkan dapat memiliki performa handal dengan efisiensi tinggi dan tegangan keluaran yang dapat menyesuaikan referensi, sehingga dirancang inverter satu fasa menggunakan teknik pemicuan SPWM dengan frekuensi sinyal carrier $20 \mathrm{kHz}$ berbasis mikrokontoler 16-bit dsPIC30f4011 dengan feedback tegangan. Pengendalian tegangan direalisasikan menggunakan sensor tegangan dan metode kontrol Proportional Integral [5].

\section{Metode}

Gambar 1 Perancangan inverter satu fasa tipe full bridge dengan kontrol tegangan proportional integral pada Penelitian ini terdiri dari beberapa blok utama, yaitu blok suplai AC 1 fasa, blok rangkaian daya, blok rangkaian kontrol, blok sensor arus ACS712-05B, blok sensor tegangan, blok modul Digital-to-Analog Converter AD7302, serta blok beban.

Blok rangkaian daya terdiri dari full-wave bridge rectifier dan inverter satu fasa. Blok rangkaian kontrol terdiri dari mikrokontroler 16-bit DSPIC30F4011 dan MOSFET driver.

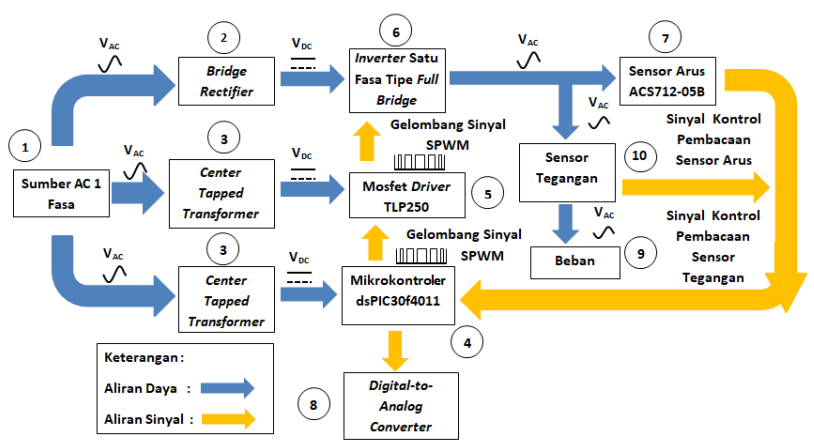

Gambar 1. Blok Diagram Perangkat Keras

Spesifikasi inverter satu fasa tipe full bridge berdasarkan Gambar 1 yang dirancang pada Penelitian ini dijelaskan sebagai berikut.

1. Sumber tegangan AC 1 fasa digunakan untuk mensuplai rangkaian daya dan rangkaian kontrol.

2. Suplai tegangan DC untuk rangkaian daya inverter diperoleh dari hasil penyearahan tegangan AC menggunakan bridge rectifier.

3. Suplai $15 \mathrm{~V}$ DC untuk rangkaian driver MOSFET dan mikrokontroler DSPIC30F4011 diperoleh dari hasil penyearahan tegangan AC keluaran trafo menggunakan center-tapped full wave rectifier.

4. Mikrokontroler 16-Bit DSPIC30F4011 digunakan untuk memproses senarai program yang bertujuan agar dapat dihasilkan inverter dengan feedback tegangan.

5. TLP250 digunakan sebagai MOSFET driver dengan suplai DC yang memiliki ground berbeda-beda pada sisi high inverter satu fasa.

6. Jenis inverter yang dirancang adalah inverter satu fasa tipe full bridge, yang terdiri dari empat buah MOSFET tipe IRF460.

7. Sensor arus ACS712-05B digunakan untuk mengukur arus keluaran inverter dan mengirim informasi berupa tegangan kepada mikrokontroler DSPIC30F4011 melalui fasilitas ADC.

8. Digital-to-Analog Converter AD7302 digunakan untuk menampilkan tegangan keluaran yang merepresentasikan arus referensi dan arus aktual yang diukur oleh sensor pada osiloskop.

9. Blok beban terdiri dari beban yang terhubung dengan keluaran inverter satu fasa. Beban yang digunakan dalam perancangan Penelitian ini adalah berupa resistor.

10. Sensor tegangan digunakan untuk mengukur tegangan keluaran inverter dan mengirim informasi berupa tegangan kepada mikrokontroler DSPIC30F4011 melalui fasilitas ADC.

\subsection{MOSFET Driver TLP250}

Rangkaian TLP250 digunakan untuk mengisolasi dan menguatkan sinyal kontrol SPWM dengan level tegangan 5 Volt yang dibangkitkan oleh mikrokontroller DSPIC30F4011 menjadi level tegangan yang lebih tinggi dengan sistem ground terpisah (level tegangan 15 Volt) dan cukup untuk memicu MOSFET (Metal Oxide Semiconductor Field Effect Transistor) sebagai driver [17].

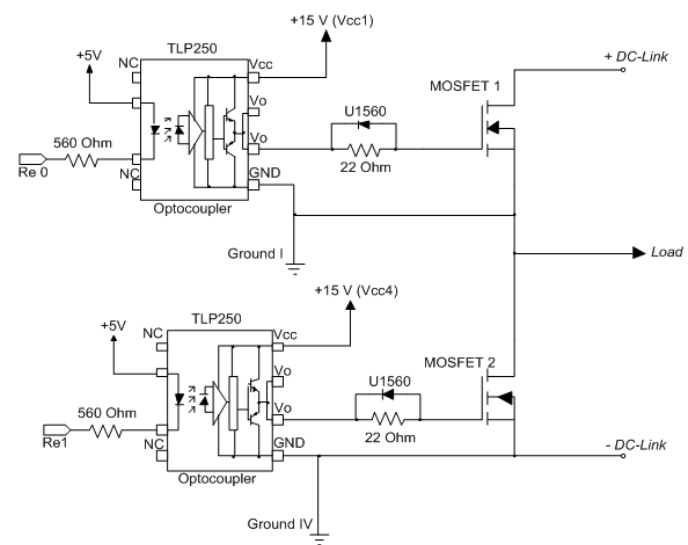

Gambar 2. Rangkaian MOSFET Driver TLP250 
MOSFET sisi atas (high-side) terhubung dengan optocoupler yang memiliki suplai DC terpisah dengan fasa lain dan MOSFET Driver sisi low, sedangkan MOSFET pada sisi bawah (low-side) terhubung dengan rangkaian optocoupler yang memiliki titik referensi ground yang sama dengan MOSFET Driver sisi low pada fasa yang lain [17].

\subsection{Sensor Arus ACS712-05B}

Sensor arus ACS712-05B digunakan sebagai perangkat pengukuran dan pembacaan nilai arus aktual yang melalui beban dalam perancangan Penelitian ini. Sensor ini bekerja dengan prinsip hall effect. Arus yang mengalir melewati sensor akan dibaca dan dikonversikan menjadi nilai tegangan yang proporsional, kemudian sinyal berupa tegangan tersebut akan dibaca oleh modul ADC pada mikrokontroler DSPIC30F4011.

Tegangan keluaran sensor akan bernilai sekitar 2,5 V saat tidak ada arus yang mengalir melewati sensor. Berdasarkan datasheet, sensitivitas sensor arus ACS71205B ini adalah sebesar $185 \mathrm{mV} / \mathrm{A}$ [12], namun jenis sensor yang digunakan sudah dilengkapi IC op-amp atau penguat sinyal TLC2272ACD yang dapat digunakan untuk mengatur nilai offset dan gain melalui dua potensiometer yang dihubungkan pada IC op-amp tersebut. Potensiometer gain diatur hingga nilai sensitivitas sensor berubah menjadi 0,5 V/A, sehingga nilai tegangan keluaran maksimal dari sensor saat arus yang terbaca sebesar 5 A sesuai dengan Persamaan 1 berikut.

$$
\begin{aligned}
& V_{\text {out }}=2,5+0,5 \cdot i \\
& V_{\text {out }}=2,5+0,5 \cdot 5 \\
& V_{\text {out }}=5 \mathrm{~V}
\end{aligned}
$$

Tegangan keluaran sensor diatur menjadi maksimal $5 \mathrm{~V}$ untuk memudahkan pembacaan oleh modul analog-todigital converter yang memiliki tegangan referensi sebesar $5 \mathrm{~V}$.

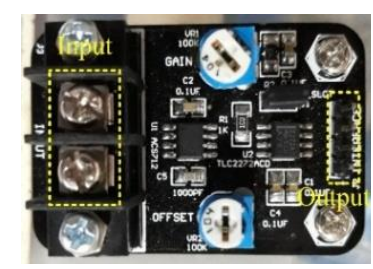

\section{Gambar 3. Sensor Arus ACS712-05B}

\subsection{Sensor Tegangan}

Sensor tegangan atau rangkaiaan pengkondisi sinyal digunakan sebagai perangkat pengukuran dan pembacaan nilai tegangan aktual yang melalui beban dalam perancangan Penelitian ini. Rangkaian pengkondisi sinyal ini terdiri dari rangkaian pembagi tegangan, rangkaian penjumlah dan rangkaian penguat [21]. seperti pada Gambar 4 berikut.

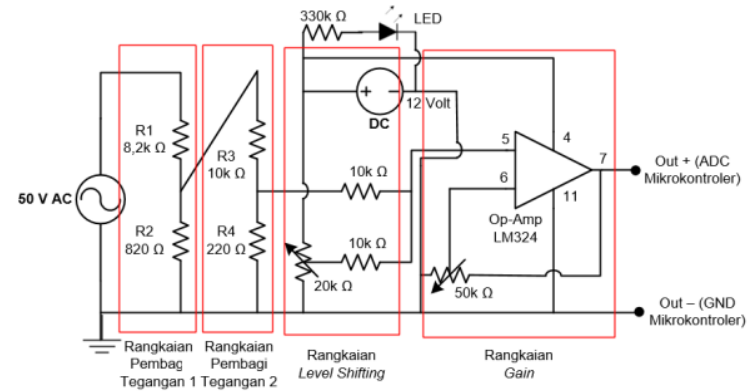

Gambar 4. Rangkaian Sensor Tegangan

Berdasarkan Gambar 4 di atas terdapat 2 rangkaian pembagi tegangan yang pertama terdiri dari resitor $8.2 \mathrm{~K}$ $\Omega(\mathrm{R} 1)$, resistor $820 \Omega(\mathrm{R} 2)$ yang disusun secara seri dan yang kedua terdiri dari resitor $10 \mathrm{~K} \Omega(\mathrm{R} 3)$, resistor $220 \Omega$ (R4) yang disusun secara seri. Perbandingan nilai dari resistor yang dipasang secara seri akan mempengaruhi besar tegangan yang lewat pada resistor pembanding, sehingga dicari kombinasi resistor yang sesuai untuk mendapatkan keluaran $\left(\mathrm{V}_{\text {out }}\right)$ yang diinginkan, berikut perhitungan pada rangkaian pembagi tegangan pertama sesuai dengan rumus [21]:

$$
\begin{aligned}
& V_{\text {out }}=\frac{R 2}{R 2+R 1} \times \operatorname{Vin} \\
& V_{\text {out }}=\frac{820}{8200+820} \times 50 \\
& V_{\text {out }}=5 \text { Volt } \\
& \text { Dimana: } \\
& \mathrm{V}_{\text {in }} \quad=\text { Tegangan keluaran inverter }(50 \mathrm{~V}) \\
& \mathrm{R}_{1} \quad=8.2 \mathrm{~K} \Omega \\
& \mathrm{R}_{2} \quad=820 \Omega
\end{aligned}
$$

Setelah melewati rangkaian pembagi tegangan pertama dan dihasilkan $\mathrm{V}_{\text {out }}$ sebesar 5 Volt, kemudian melewati rangkaian pembagi tegangan yang kedua, berikut perhitungan pada rangkaian pembagi tegangan kedua :

$V_{\text {out }}=\frac{R 4}{R 4+R 3} \times$ Vin
$V_{\text {out }}=\frac{220}{10000+220} \times 5$
$V_{\text {out }}=0.108$ Volt

Dimana:

$\mathrm{V}_{\text {in }} \quad=$ Tegangan hasil rangkaian pembagi tegangan pertama $(5 \mathrm{~V})$

$\mathrm{R}_{3} \quad=10 \mathrm{~K} \Omega$

$\mathrm{R}_{4} \quad=220 \Omega$

Setelah didapatkan tegangan $0,108 \mathrm{~V}$ dari rangkaian pembagi tegangan, setelah itu melewati rangkaian level shifting, yang terdiri dari sebuah potensiometer $20 \mathrm{~K} \Omega$ dan 2 buah resistor $10 \mathrm{~K} \Omega$, dimana rangkaian ini berfungsi untuk memberikan offset pada sinyal gelombang tegangan sinus agar dihasilkan sinyal 
gelombang tegangan sinus namun berada di atas garis referensi dan titik tengah osilasi gelombang yang berada pada $2,5 \mathrm{~V}$.

Gain circuit atau rangkaian penguat menggunakan IC $O p$ Amp LM324N digunakan untuk mengatur besar magnitude, sehingga didapatkan besar nilai sinyal gelombang tegangan yang sesuai dengan ADC mikrokontroler yaitu $5 \mathrm{Vpp}$. Realisasi perangkat keras tegangan yang digunakan dalam perancangan Penelitian ini ditunjukkan pada Gambar 5 berikut.

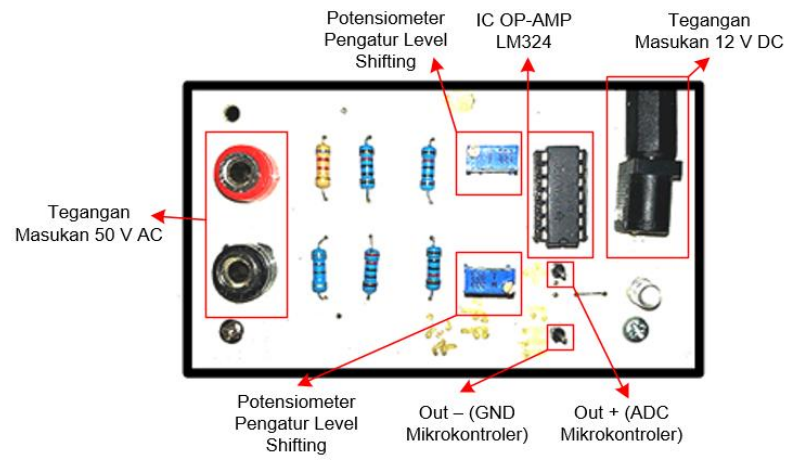

Gambar 5. Realisasi Sensor Tegangan

\subsection{Perancangan Kontrol Proportional Integral dan Proportional Resonant}

Metode kontrol yang digunakan pada Penelitian ini yaitu Kontrol Proportional Integral dan Proportional Resonant. Sinyal kontrol Proportional Integral digunakan untuk memberikan penguatan pada proses umpan balik pada nilai tegangan keluaran dari inverter, sedangkan sinyal kontrol Proportional Resonant digunakan untuk memberikan penguatan pada proses umpan balik pada nilai arus keluaran dari inverter.

Pada proses umpan balik tegangan nilai error $(e 1)$ diperoleh dari hasil pengurangan nilai tegangan aktual yang diukur oleh sensor tegangan $(x)$ dan nilai referensi tegangan yang diberikan lewat potensiometer $(u)$. Setelah nilai ( $e 1)$ didapatkan, kontroler akan menghitung nilai error dengan nilai penguatan untuk menghasilkan sinyal kontrol $\left(U_{P I}\right)$. Gambar 6 menunjukkan diagram blok dari kontroler proportional integral secara umum.

Error 1

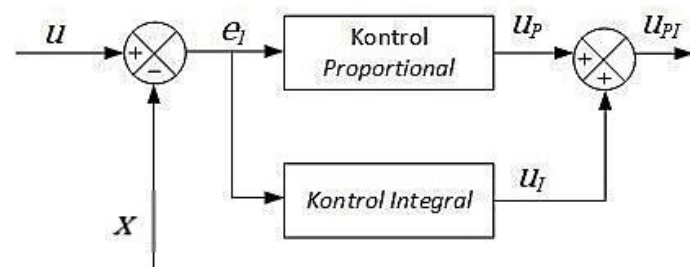

Gambar 6. Diagram Blok Kontrol Proportional Integral
Berikut merupakan senarai program yang dibuat dengan menggunakan bahasa pemrograman $\mathrm{C}$ pada perancangan feedback tegangan pada Penelitian ini :

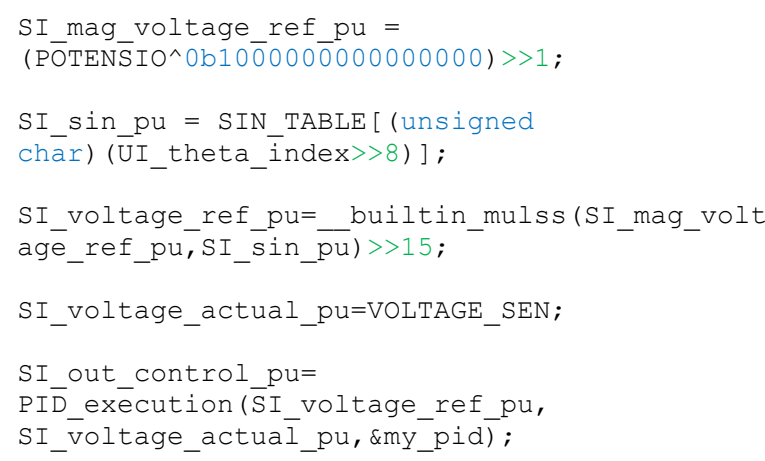

Senarai program feedback tegangan tersebut berfungsi sebagai pengumpan balik tegangan keluaran dari inverter dengan memberikan penguatan dengan menggunakan metode kontrol Proportional Integral. Pada mulanya, program memproses nilai masukan ADC yang digunakan sebagai nilai referensi tegangan yang direpresentasikan dengan menggunakan potensiometer, setelah didapatkan nilai ADC tersebut kemudian program memberikan perintah untuk membangkitkan gelombang sinusoidal yang kemudian akan digunakan sebagai variabel pengali yaitu antara nilai referensi dari potensiometer dengan gelombang sinusoidal supaya dihasilkan magnitude referensi gelombang tegangan (sinyal kontrol $u$ ) yang akan diproses selanjutnya oleh algoritma.

Setelah didapatkan sinyal kontrol $u$, kemudian program mendefinisikan bahwa nilai sinyal kontrol tegangan aktual didapatkan dari sensor tegangan yang telah tersambung dengan ADC (sinyal kontrol $x$ ). Kemudian program melakukan proses perkalian dengan menggunakan register builtin mulss antara sinyal kontrol $u$ dengan sinyal kontrol $x$ dan memberikan penguatan dengan menggunakan register PID_execution pada hasil perkalian tersebut dengan metode kontrol Proportional Integral supaya dihasilkan nilai sinyal kontrol yang cukup mendekati nilai sinyal kontrol $u$ yang selanjutnya disebut dengan sinyal kontrol $U_{P I}$.

Sinyal kontrol $U_{P I}$ kemudian dikalikan dengan nilai arus aktual yang diukur oleh sensor arus (sinyal kontrol $y$ ), sehingga menghasilkan nilai $\left(e_{2}\right)$. Nilai $\left(e_{2}\right)$ akan dihitung oleh kontroler dengan nilai penguatan yang dihasilkan dari kontrol proportional resonant untuk menghasilkan sinyal kontrol $\left(U_{P R}\right)$ yang selanjutnya akan digunakan sebagai acuan pembangkitan SPWM. Gambar 7 menunjukkan diagram blok dari kontroler proportional resonant secara umum. 


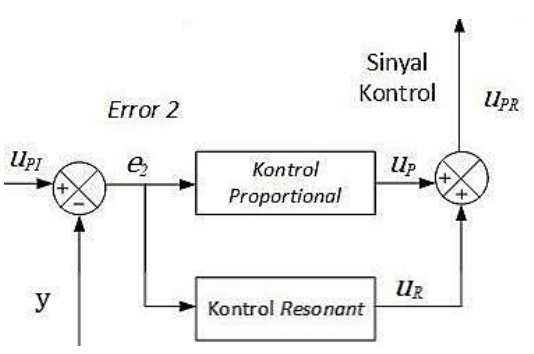

Gambar 7. Diagram Blok Kontrol Proportional Resonant

Berikut merupakan senarai program yang dibuat dengan menggunakan bahasa pemrograman $\mathrm{C}$ pada perancangan feedback arus pada Penelitian ini :

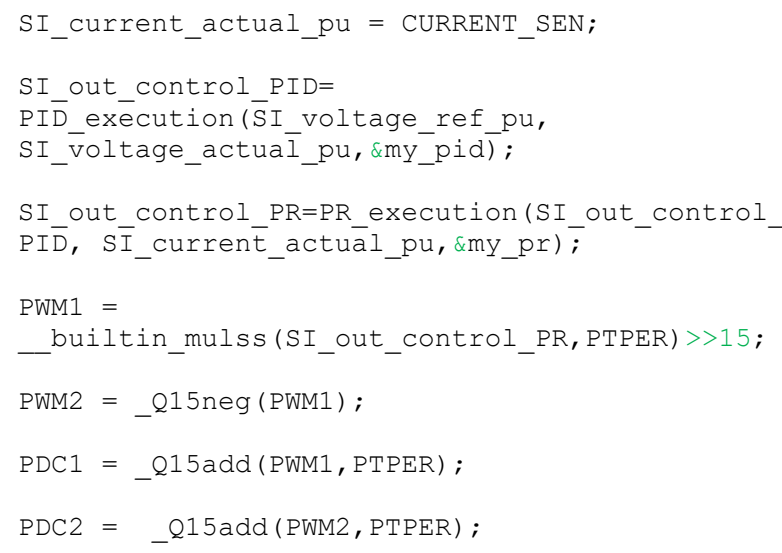

Senarai program diatas berfungsi sebagai pengumpan balik arus pada inverter dengan memberikan penguatan dengan menggunakan metode kontrol Proportional Resonant. Pada mulanya, program mendefiniskan bahwa sinyal kontrol arus yang selanjutnya disebut dengan sinyal kontrol $y$ didapatkan dari output sensor arus yang telah terkoneksikan dengan ADC mikrokontroler. Kemudian program memberikan perintah untuk melakukan proses penguatan menggunakan metode kontrol Proportional Integral dengan register PID_execution pada proses feedback tegangan yang kemudian akan dihasilkan sinyal kontrol $U_{P I}$.

Setelah didapatkan sinyal kontrol $U_{P I}$, kemudian program memberikan perintah untuk melakukan proses penguatan dengan menggunakan register PR_execution pada proses perkalian antara sinyal kontrol $U_{P I}$ dengan sinyal kontrol $y$ dengan menggunakan metode kontrol Proportional Resonant, sehingga akan didapatkan sinyal kontrol $U_{P R}$.

Sinyal kontrol $U_{P R}$ kemudian digunakan sebagai sinyal referensi pembangkitan SPWM1 dengan cara memberikan proses perkalian dengan sinyal PTPER menggunakan register _builtin_mulss. Setelah didapatkan SPWM1, dengan cara memberikan proses negatif menggunakan register Q15neg pada program maka akan dihasilkan SPWM2, dimana antara SPWM1 dan SPWM2 saling berkomplemen.
Berikut merupakan gambar diagram blok kontrol secara keseluruhan pada perancangan inverter dengan feedback tegangan dengan metode kontrol Proportional Integral dan feedback arus dengan metode kontrol Proportional Resonant.

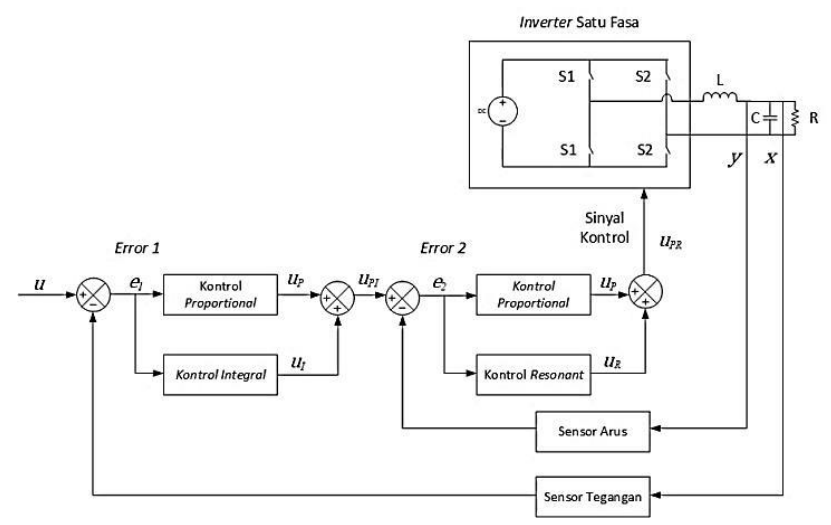

Gambar 8. Diagram Blok Kontrol Proportional Integral dan Proportional Resonant pada Inverter

Gambar 8 merupakan rancangan rangkaian kontrol pada inverter dengan feedback tegangan dan arus. Tegangan keluaran inverter diumpan-balik dengan menggunakan metode kontrol Proportional Integral dan arus keluaran inverter diumpan-balik dengan menggunakan metode kontrol Proportional Resonant .

Proses feedback tegangan keluaran inverter menggunakan sensor tegangan sebagai pengukur tegangan keluaran yang dihubungkan secara paralel pada keluaran inverter. Keluaran sensor tegangan akan menghasilkan sinyal kontrol $\mathrm{x}$, kemudian sinyal kontrol $\mathrm{x}$ masuk ke ADC mikrokontroler untuk dilakukan proses pembandingan dengan tegangan referensi (sinyal kontrol $u$ ), hasil pembandingan tersebut akan menghasilkan error1. Sinyal kontrol error1 akan diberikan penguatan oleh metode kontrol proportional integral dan akan dihasilkan sinyal kontrol $U_{P I}$

Proses feedback arus keluaran inverter menggunakan sensor arus sebagai pengukur arus keluaran yang dihubungkan secara seri pada keluaran inverter. Keluaran sensor arus akan menghasilkan sinyal kontrol y, kemudian sinyal kontrol y masuk ke ADC mikrokontroler untuk dilakukan proses pembandingan dengan arus referensi yang didapat dari sinyal kontrol $U_{\mathrm{PI}}$, hasil pembandingan tersebut akan menghasilkan error2. Sinyal kontrol error2 akan diberikan penguatan oleh metode kontrol proportional proportional dan akan dihasilkan sinyal kontrol UPR. Sinyal kontrol UPR yang berupa gelombang sinus akan digunakan sebagai sinyal carrier pada pembangkitan SPWM. 
3. Hasil dan Analisis

\subsection{Pengujian Gelombang Keluaran Rangkaian Kontrol}

\subsubsection{Pengujian Gelombang Keluaran} DSPIC30F4011

Pengujian dilakukan untuk memastikkan bahwa modul PWM pada DSPIC30F4011 dapat membangkitkan sinyal kontrol dalam mode komplementer dengan adanya dead time sebesar $1 \mathrm{uS}$ antara pin PWMxL dan PWMxL. Pengujian dilakukan dengan program PWM open loop dengan frekuensi PWM $20 \mathrm{kHz}$

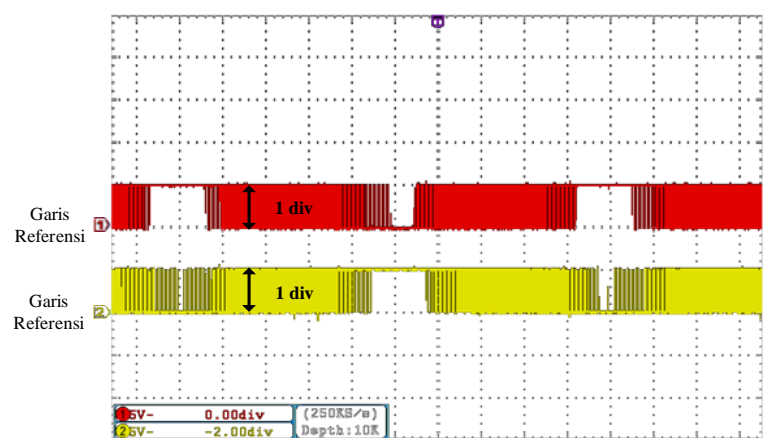

Gambar 9. Gelombang Keluaran PWM Open Loop

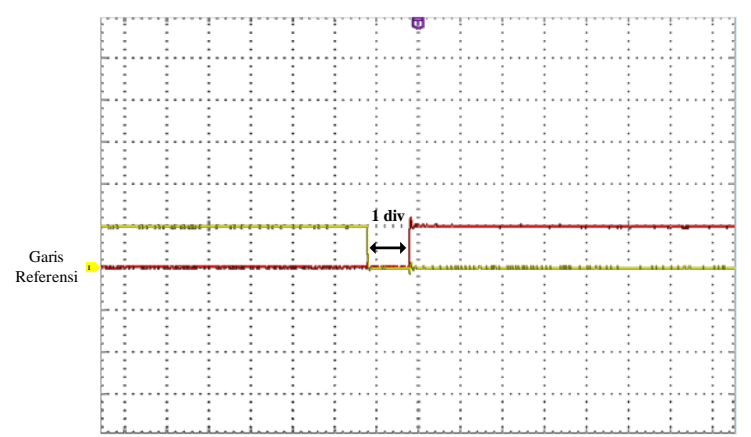

Gambar 10. Dead Time pada Keluaran PWM Open Loop

Hasil pengujian keluaran DSPIC30F4011 pada SPWM open loop menunjukkan bahwa sinyal kontrol bekerja dalam mode komplementer serta adanya dead time sebesar $1 \mathrm{uS}$ antara PWM sisi high dan PWM sisi low.

\subsubsection{Pengujian Gelombang Keluaran MOSFET Driver TLP250}

Pengujian pada rangkaian ini dilakukan untuk mengetahui dan memastikan gelombang tegangan keluaran dari MOSFET driver TLP250 telah sesuai dengan perancangan dan dapat digunakan untuk pemicuan MOSFET.

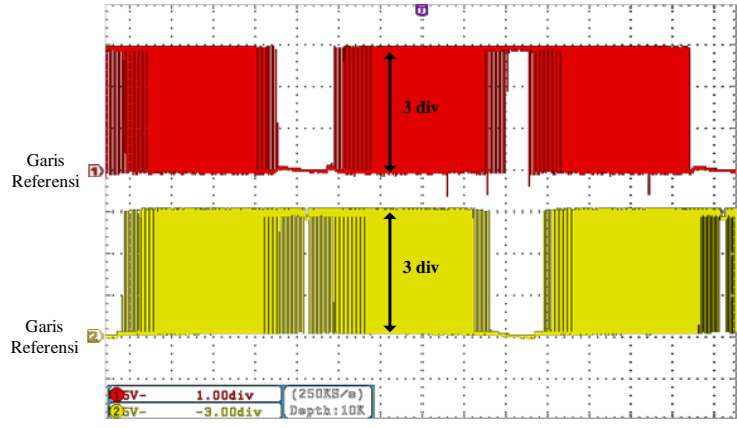

Gambar 11. Gelombang Keluaran Driver MOSFET TLP250

Hasil pengujian gelombang keluaran dari MOSFET driver TLP250 telah sesuai dengan perancangan dan dapat digunakan untuk memicu MOSFET.

\subsection{Pengujian Sensor Arus ACS712-05B}

Pengujian sensor arus ACS712-05B dilakukan dengan mengukur tegangan keluaran sensor yang telah dikalibrasi sebelumnya saat dialiri arus sebesar 1 A. Arus diberikan dengan cara memasang beban resistif secara seri dengan sumber tegangan $\mathrm{AC}$ yang diatur sedemikian rupa hingga nilai arus yang mengalir adalah $1 \mathrm{~A}$.

Nilai arus yang diukur oleh sensor direpresentasikan secara proporsional oleh tegangan keluaran sensor. Sebelumnya pada perancangan sensor arus telah diatur nilai offset tegangan keluaran sensor adalah $2,5 \mathrm{~V}$ dan sensitivitas pembacaan arus oleh sensor adalah 0,5 V/A.

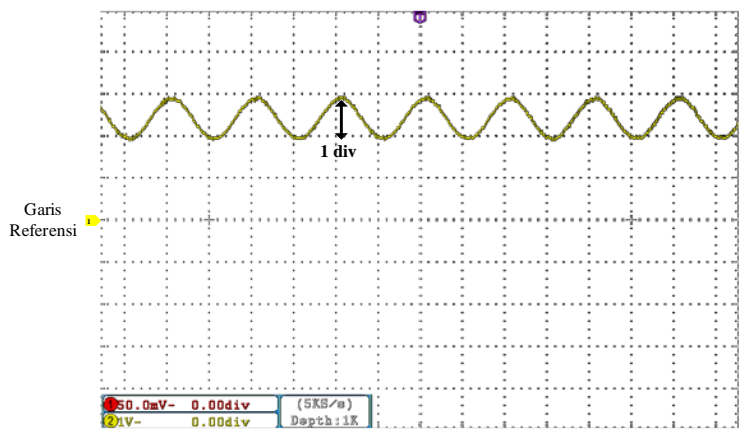

Gambar 12. Gelombang Keluaran Sensor Arus ACS712-05B $(\mathbf{I}=\mathbf{1}$ A $)$

Nilai tegangan puncak ke puncak pada pengujian sensor dalam Gambar 12 memiliki jumlah div 5 dengan skala $\mathrm{V} /$ div $=1 \mathrm{~V}$ dengan faktor pengali probe $1 \mathrm{x}$. Hal ini sudah sesuai dengan perancangan dimana saat arus $=1 \mathrm{~A}$ maka diperoleh tegangan keluaran sensor sebagai berikut.

$$
\begin{aligned}
& V_{\text {out }}=2,5+0,5 \cdot i \\
& V_{\text {out }}=2,5+0,5 \cdot 1 \\
& V_{\text {out }}=3 \mathrm{~V}
\end{aligned}
$$




\subsection{Pengujian Sensor Tegangan}

Pengujian sensor tegangan dilakukan dengan mengukur tegangan keluaran sensor yang telah dikalibrasi sebelumnya saat diberi tegangan masukan 50 Volt dari keluaran inverter.

Nilai tegagan yang diukur oleh sensor direpresentasikan secara proporsional oleh tegangan keluaran sensor. Sebelumnya pada perancangan sensor tegangan telah diatur nilai offset tegangan keluaran sensor adalah 2,5 V.

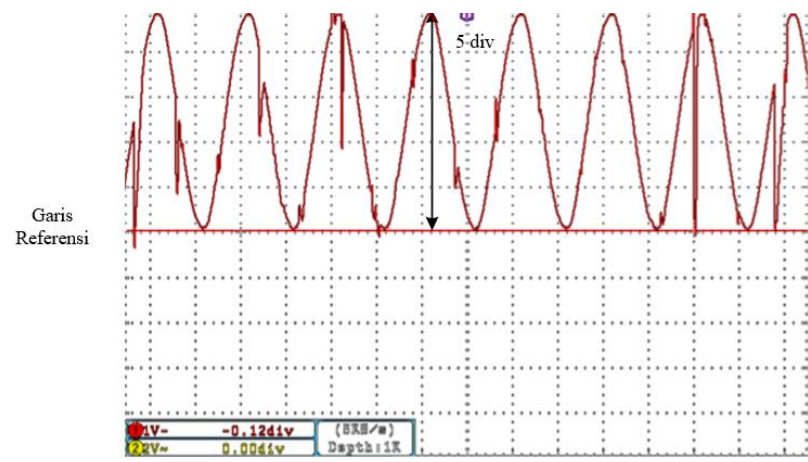

Gambar 13. Gelombang Keluaran Sensor Tegangan dengan Tegangan Masukan 50 Volt

Nilai tegangan puncak ke puncak pada pengujian sensor dalam Gambar 13 memiliki jumlah 5 div dengan skala $\mathrm{V} /$ div $=1 \mathrm{~V}$ dengan faktor pengali probe $1 \mathrm{x}$. Hal ini sudah sesuai dengan perancangan dimana saat tegangan masukan sensor $=50$ Volt maka diperoleh tegangan keluaran sensor sebagai berikut.

$$
\begin{aligned}
& V_{\text {out }}=2,5+0,5 \cdot i \\
& V_{\text {out }}=2,5+0,5 \cdot 5 \\
& V_{\text {out }}=5 \mathrm{~V}
\end{aligned}
$$

\subsection{Pengujian Keluaran Inverter dengan Metode Kontrol Open Loop}

Pengujian ini dilakukan untuk mengetahui bentuk Pengujian bertujuan untuk mengamati bentuk gelombang dan magnitude tegangan keluaran inverter satu fasa yang dipicu oleh SPWM open loop dimana tegangan keluaran inverter tidak diumpan-balikkan pada sistem. Tegangan Referensi yang diberikan adalah sebesar 2,5 Volt dan 5 Volt serta tegangan masukan sebesar 50 Volt. Referensi tegangan 2,5 Volt merepresentasikan tegangan keluaran inverter sebesar 25 Volt peak sedangkan Referensi tegangan 5 Volt merepresentasikan tegangan keluaran inverter sebesar 50 Volt peak. Hasil pengujian tegangan keluaran inverter dengan SPWM open loop pada beban $47 \mathrm{ohm}$ adalah sebagai berikut:

Hasil pengujian tegangan keluaran inverter open loop dengan tegangan referensi 2,5 Volt menghasilkan tegangan sebesar 24 Volt peak didapatkan selisih tegangan sebesar 1 Volt dari tegangan referensi. Pengujian dengan tegangan referensi 5 Volt menghasilkan tegangan sebesar 44 Volt peak didapatkan selisih tegangan sebesar 6 Volt. Selisih antara tegangan keluaran dan tegangan referensi tersebut disebabkan oleh adanya drop voltage karena beban yang dipasang pada terminal keluaran rangkaian pengujian inverter sebesar $47 \mathrm{Ohm}$ serta tidak adanya umpan balik pada sistem yang menyebabkan tidak adanya penguatan pada metode kontrol open loop.

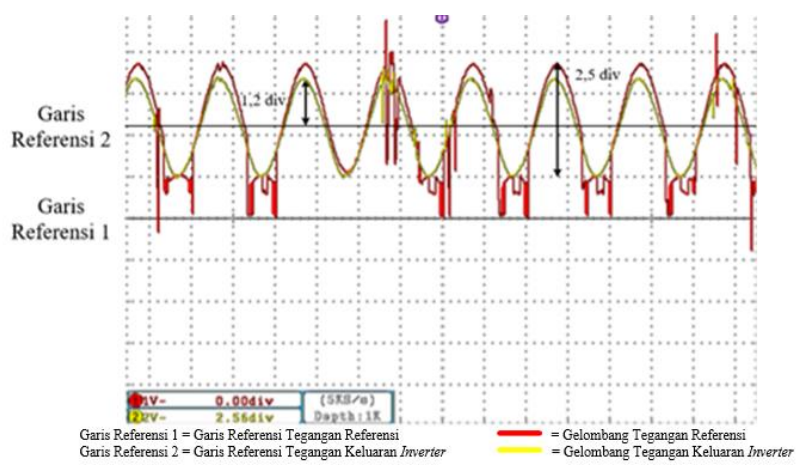

Gambar 14. Tegangan Keluaran Inverter Open Loop dengan Referensi 2,5 Volt.

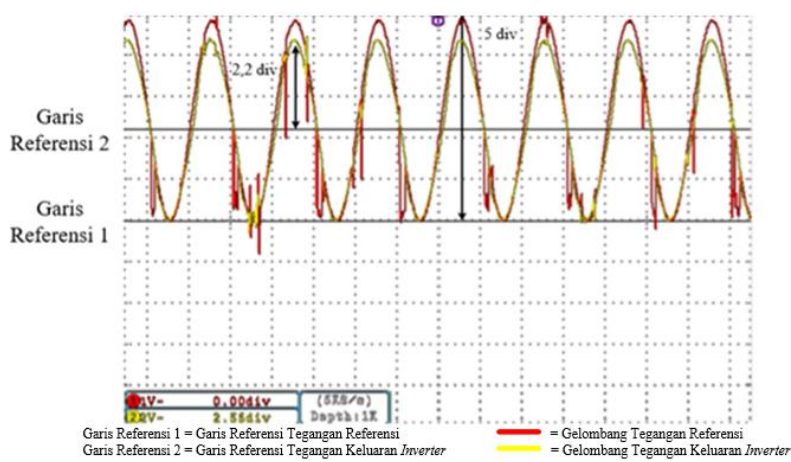

Gambar 15. Tegangan Keluaran Inverter Open Loop dengan Referensi 5 Volt

\subsection{Pengujian Keluaran Inverter dengan Metode Kontrol Closed Loop}

Pengujian keluaran inveter dengan kontrol closed loop bertujuan untuk mengetahui dan menganalisa bentuk gelombang tegangan referensi, gelombang tegangan keluaran inverter, dan arus aktual dengan pengaruh penguatan sinyal kontrol proportional integral dan penggabungan penguatan sinyal kontrol antara proportional integral dengan sinyal kontrol proportional resonant. Pengujian diamati lewat terminal keluaran tegangan DAC yang merepresentasikan tegangan referensi dan arus aktual serta terminal beban untuk tegangan keluaran. Pengujian dilakukan dengan menggunakan 2 metode kontrol closed loop, yaitu closed loop single dan closed loop cascade. Metode kontrol closed loop single menggunakan penguatan proportional integral yang diberikan di proses feedback tegangan, sedangkan metode kontrol closed loop cascade 
menggunakan penguatan proportional integral yang diberikan pada proses feedback tegangan serta propotional resonant yang diberikan pada proses feedback arus.

\subsubsection{Pengujian Tegangan Keluaran Inverter dengan Metode Kontrol Closed Loop Single}

Pengujian keluaran inveter dengan kontrol closed loop single bertujuan untuk mengetahui bentuk serta menganalisa gelombang tegangan referensi dan tegangan keluaran inverter, setelah diberikan penguatan dengan metode kontrol proportional integral. Pengujian dilakukan dengan tegangan masukan 50 Volt dan tegangan referensi sebesar 2,5 Volt serta 5 Volt.

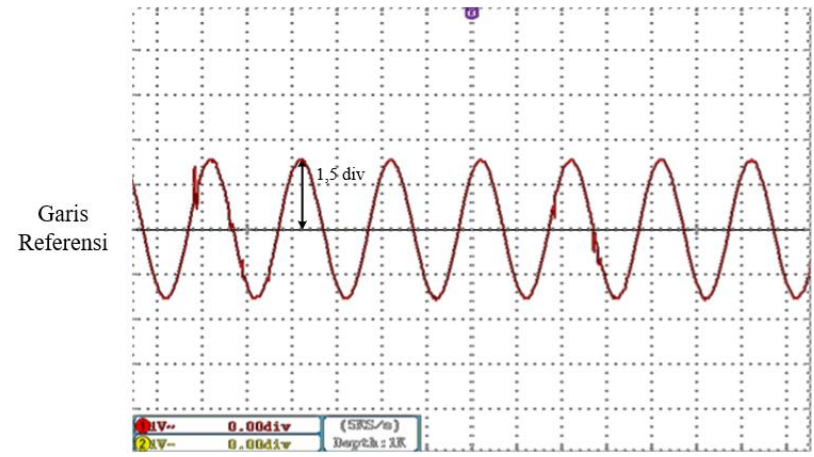

Gambar 16. Gelombang Tegangan Keluaran Inverter dengan Tegangan Referensi 2,5 Volt

Pengamatan tegangan keluaran inverter pada Gambar 16 dilakukan dengan pengaturan oscilloscope yaitu faktor pengali probe $10 \mathrm{x}$, v/div $=1 \mathrm{~V}$, dan $\mathrm{t} / \mathrm{div}=10 \mathrm{~ms}$. Berdasarkan hasil pengamatan melalui Oscilloscope diperoleh tegangan pada keluaran Inverter sebagai berikut

$$
\begin{aligned}
& V_{A C} \text { peak }=1,5 \mathrm{div} \cdot 1 \mathrm{~V} / \mathrm{div} \cdot 10 \\
& V_{A C} \text { peak }=15 \mathrm{volt}
\end{aligned}
$$

Perbandingan antara perhitungan tegangan keluaran inverter yang menghasilkan tegangan sebesar 15 Volt peak dengan tegangan referensi 2,5 Volt didapatkan selisih tegangan sebesar 10 Volt, hal tersebut disebabkan oleh adanya drop voltage karena beban yang dipasang pada terminal keluaran rangkaian pengujian inverter sebesar $47 \mathrm{Ohm}$, serta kurangnya penguatan pada metode kontrol proportional integral.

Pengamatan tegangan keluaran inverter pada Gambar 17 dilakukan dengan pengaturan oscilloscope yaitu faktor pengali probe $10 \mathrm{x}, \mathrm{v} / \mathrm{div}=1 \mathrm{~V}$, dan $\mathrm{t} / \mathrm{div}=10 \mathrm{~ms}$. Berdasarkan hasil pengamatan melalui Oscilloscope diperoleh tegangan pada keluaran Inverter sebagai berikut

$$
\begin{aligned}
& V_{A C} \text { peak }=2,8 \mathrm{div} \cdot 1 \mathrm{~V} / \mathrm{div} \cdot 10 \\
& V_{A C} \text { peak }=28 \mathrm{volt}
\end{aligned}
$$

Perbandingan antara perhitungan tegangan keluaran inverter yang menghasilkan tegangan sebesar 28 Volt peak dengan tegangan referensi 5 Volt didapatkan selisih tegangan sebesar 22 Volt, hal tersebut disebabkan oleh adanya drop voltage karena beban yang dipasang pada terminal keluaran rangkaian pengujian inverter sebesar 47 Ohm, serta kurangnya penguatan pada metode kontrol proportional integral.

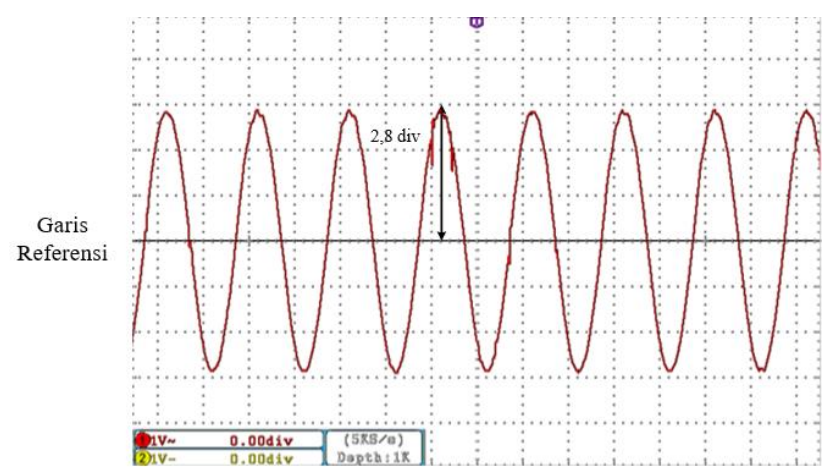

Gambar 17. Gelombang Tegangan Keluaran Inverter dengan Tegangan Referensi 5 Volt

\subsubsection{Pengujian Tegangan Keluaran Inverter dengan Metode Kontrol Closed Loop Cascade}

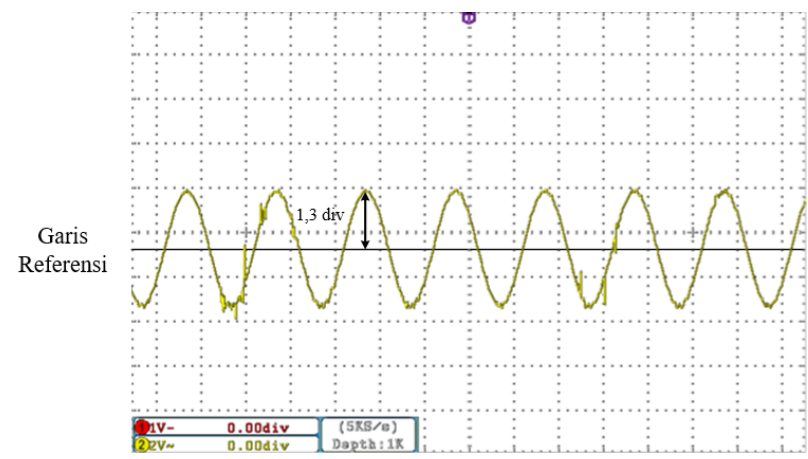

Gambar 18. Gelombang Tegangan Keluaran Inverter dengan Tegangan Referensi 2,5 Volt

Pengujian keluaran inveter dengan kontrol closed loop cascade bertujuan untuk mengetahui bentuk serta menganalisa gelombang tegangan referensi dan tegangan keluaran inverter, setelah diberikan penguatan dengan metode kontrol proportional integral yang diberikan pada proses feedback tegangan serta propotional resonant yang diberikan pada proses feedback arus. Pengujian dilakukan dengan tegangan masukan 50 Volt dan tegangan referensi sebesar 2,5 Volt serta 5 Volt.

Pengamatan tegangan keluaran inverter pada Gambar 18 dilakukan dengan pengaturan oscilloscope yaitu faktor pengali probe $10 \mathrm{x}$, v/div $=2 \mathrm{~V}$, dan $\mathrm{t} / \mathrm{div}=10 \mathrm{~ms}$. Berdasarkan hasil pengamatan melalui Oscilloscope diperoleh tegangan pada keluaran Inverter sebagai berikut 
$V_{\text {AC }}$ peak $=1,3 \mathrm{div} \cdot 2 \mathrm{~V} / \mathrm{div} \cdot 10$

$V_{\text {AC }}$ peak $=26$ volt

Perbandingan antara perhitungan tegangan keluaran inverter yang menghasilkan tegangan sebesar 26 Volt peak dengan tegangan referensi 2,5 Volt didapatkan selisih tegangan sebesar 1 Volt, hal tersebut membuktikan bahwa dengan menggunakan metode kontrol closed loop dengan penguatan proportional integral, tegangan keluaran inverter dapat dipertahankan sesuai dengan kondisi idealnya.

Setelah didapatkan nilai tegangan keluaran inverter sebesar 26 Volt peak, kemudian tegangan tersebut dijadikan referensi arus pada feedback arus yang kemudian diberikan penguatan proportional resonant. Setiap 25 Volt peak merepresentasikan referensi arus sebesar 0,5 Ampere. Jadi nilai tegangan keluaran inverter sebesar 26 Volt peak merepresentasikan referensi arus sebesar 0,52 Ampere. Gambar 19 berikut merupakan arus aktual inverter dengan beban sebesar 47 Ohm dengan referensi arus 0,52 Ampere.

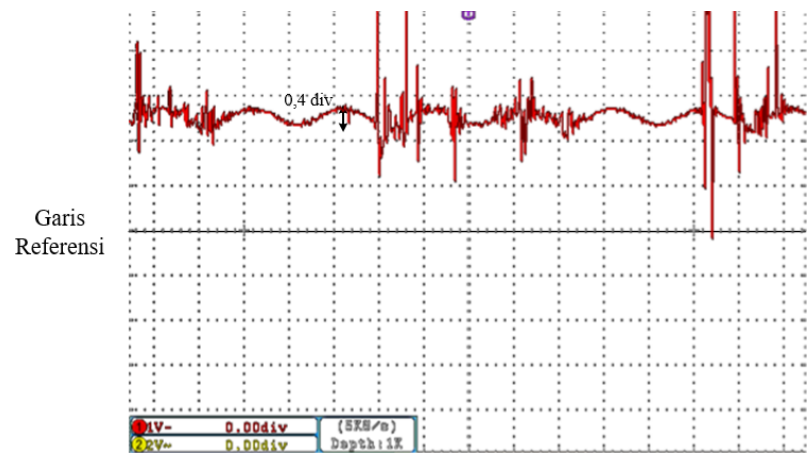

Gambar 19. Arus aktual inverter dengan referensi arus 0,52 Ampere

Pengamatan arus keluaran inverter dilakukan dengan pengaturan oscilloscope yaitu faktor pengali probe $1 \mathrm{x}$, $\mathrm{v} /$ div $=1 \mathrm{~V}$, dan $\mathrm{t} / \mathrm{div}=10 \mathrm{~ms}$. Berdasarkan hasil pengamatan melalui Oscilloscope diperoleh arus aktual inverter sebagai berikut :

$$
\begin{aligned}
& I_{A C}=0,4 \mathrm{div} \cdot 1 \mathrm{~V} / \mathrm{div} \cdot 1 \\
& I_{A C}=0,4 \text { Ampere }
\end{aligned}
$$

Perbandingan antara perhitungan arus aktual inverter pada Gambar 19 yang menghasilkan arus sebesar 0,4 Ampere dengan arus referensi 0,52 Ampere didapatkan selisih arus sebesar 0,12 Ampere. Hal tersebut membuktikan bahwa dengan feedback arus dengan penguatan proportional resonant didapatkan hasil yang mendekati ideal. Selisih antara arus referensi dengan aktual sebesar 0,12 dapat disebabkan oleh noise yang ada pada arus aktual.

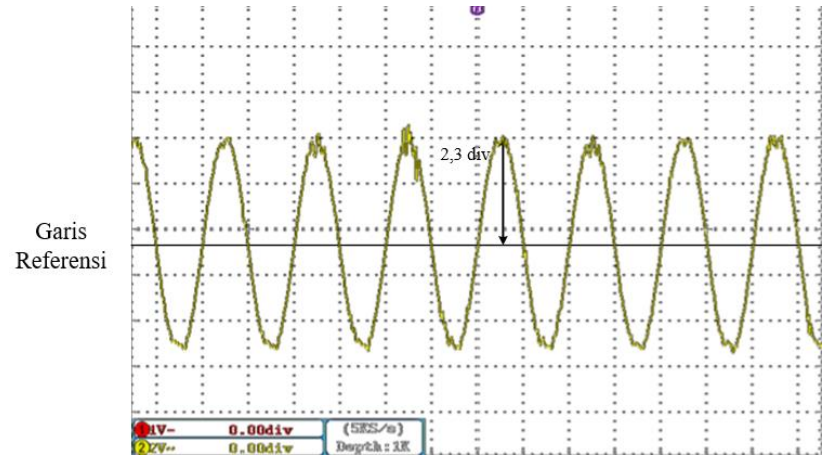

Gambar 20. Gelombang Tegangan Keluaran Inverter dengan Tegangan Referensi 5 Volt

Pengamatan tegangan keluaran inverter pada Gambar 20 dilakukan dengan pengaturan oscilloscope yaitu faktor pengali probe $10 \mathrm{x}, \mathrm{v} / \mathrm{div}=2 \mathrm{~V}$, dan $\mathrm{t} / \mathrm{div}=10 \mathrm{~ms}$. Berdasarkan hasil pengamatan melalui Oscilloscope diperoleh tegangan pada keluaran Inverter sebagai berikut

$$
\begin{aligned}
& V_{A C} \text { peak }=2,3 \mathrm{div} \cdot 2 \mathrm{~V} / \mathrm{div} \cdot 10 \\
& V_{A C} \text { peak }=46 \mathrm{volt}
\end{aligned}
$$

Perbandingan antara perhitungan tegangan keluaran inverter yang menghasilkan tegangan sebesar 46 Volt peak dengan tegangan referensi 5 Volt didapatkan selisih tegangan sebesar 4 Volt, hal tersebut membuktikan bahwa dengan menggunakan metode kontrol closed loop dengan penguatan proportional integral, tegangan keluaran inverter dapat dipertahankan sesuai dengan kondisi idealnya.

Setelah didapatkan nilai tegangan keluaran inverter sebesar 46 Volt peak, kemudian tegangan tersebut dijadikan referensi arus pada feedback arus yang kemudian diberikan penguatan proportional resonant. Setiap 50 Volt peak merepresentasikan referensi arus sebesar 1 Ampere. Jadi nilai tegangan keluaran inverter sebesar 46 Volt peak merepresentasikan referensi arus sebesar 0,92 Ampere. Gambar 21 berikut merupakan arus aktual inverter dengan beban sebesar 47 Ohm dengan referensi arus 0,92 Ampere.

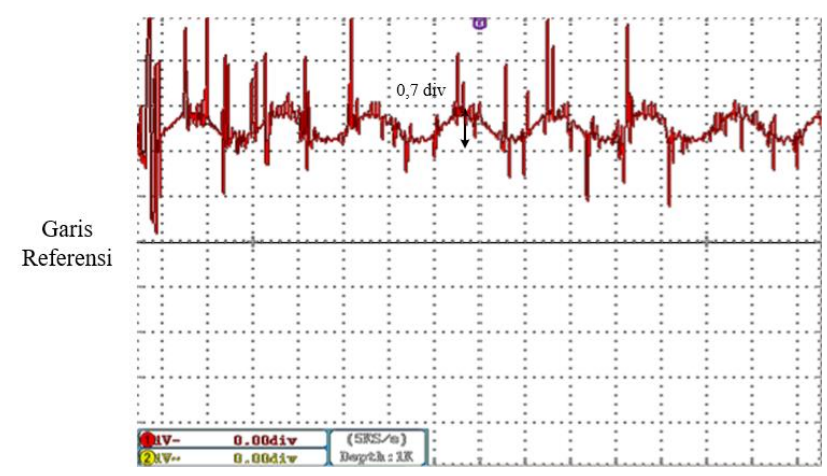

Gambar 21. Arus aktual inverter dengan referensi arus 0,92 Ampere 
Pengamatan arus keluaran inverter dilakukan dengan pengaturan oscilloscope yaitu faktor pengali probe $1 \mathrm{x}$, $\mathrm{v} /$ div $=1 \mathrm{~V}$, dan $\mathrm{t} / \mathrm{div}=10 \mathrm{~ms}$. Berdasarkan hasil pengamatan melalui Oscilloscope diperoleh arus aktual inverter sebagai berikut :

$$
\begin{aligned}
& I_{A C}=0,7 \mathrm{div} \cdot 1 \mathrm{~V} / \mathrm{div} \cdot 1 \\
& I_{A C}=0,7 \text { Ampere }
\end{aligned}
$$

Perbandingan antara perhitungan arus aktual inverter pada Gambar 21 yang menghasilkan arus sebesar 0,7 Ampere dengan arus referensi 0,92 Ampere didapatkan selisih arus sebesar 0,22 Ampere. Hal tersebut membuktikan bahwa dengan feedback arus dengan penguatan proportional resonant didapatkan hasil yang mendekati ideal. Selisih antara arus referensi dengan aktual sebesar 0,22 dapat disebabkan oleh noise yang ada pada arus aktual.

\subsection{Perbandingan Pengujian Keluaran Inverter Satu Fasa SPWM dengan Metode Kontrol Open Loop dan Closed Loop}

Pada subbab ini akan dilakukan analisa pada keluaran inverter dengan perbandingan penggunaan metode kontrol open loop dan closed loop dengan Vdc 50 Volt, dan variasi tegangan referensi sebesar 2,5 Volt peaktopeak dan 5 Volt peaktopeak. Berikut data perbandingan yang disajikan dalam Tabel 1

Tabel 1. Data perbandingan keluaran inverter satu fasa SPWM dengan metode kontrol open loop dan closed loop

\begin{tabular}{lccccccccc}
\hline \multirow{2}{*}{ Vdc } & \multicolumn{2}{c}{ Tegangan } & \multicolumn{2}{c}{ Open Loop } & \multicolumn{4}{c}{ Closed Loop } \\
\cline { 6 - 10 }$(\mathrm{V})$ & \multicolumn{2}{c}{ Referensi } & \multicolumn{2}{c}{ Single } & \multicolumn{2}{c}{ Cascade } \\
& $\mathrm{Vpp}$ & $\mathrm{V}$ & $\mathrm{Vp}$ & $\mathrm{V}$ & $\mathrm{Vp}$ & $\mathrm{V}$ & $\mathrm{Vp}$ & $\mathrm{V}$ \\
\hline \multirow{2}{*}{50} & 2,5 & 17,85 & 24 & 17,14 & 15 & 10,71 & 26 & 18,57 \\
& 5 & 35,71 & 44 & 31,42 & 28 & 20 & 46 & 32,85 \\
\hline
\end{tabular}

Keterangan :

$\begin{array}{ll}\mathrm{V} & =\text { Volt } \\ \mathrm{Vpp} & =\text { Volt peaktopeak } \\ \mathrm{Vp} & =\text { Volt peak }\end{array}$

Dari Tabel 1 dapat diketahui bahwa pada pengujian variasi Vdc 50 Volt dengan tegangan referensi 2,5 Volt peaktopeak terdapat selisih antara tegangan keluaran inverter dengan tegangan referensi pada semua metode kontrol. Pengujian dengan metode kontrol open loop didapatkan selisih -0,71 Volt, metode kontrol closed loop single didapatkan selisih tegangan -7,14 Volt, dan metode kontrol closed loop cascade didapatkan selisih tegangan $+0,72$ Volt.

Pengujian dengan tegangan referensi 5 Volt peaktopeak terdapat selisih antara tegangan keluaran inverter dengan tegangan referensi pada semua metode kontrol. Pengujian dengan metode kontrol open loop didapatkan selisih -4,29 Volt, metode kontrol closed loop single didapatkan selisih tegangan -15,71 Volt, dan metode kontrol closed loop cascade didapatkan selisih tegangan -2,86 Volt.

Berdasarkan analisa perbandingan antara metode kontrol tersebut, dapat disimpulkan bahwa metode kontrol open loop menghasilkan tegangan keluaran inverter yang cukup mendekati tegangan referensi yang telah diatur. Metode kontrol closed loop single menghasilkan tegangan keluaran inverter yang belum cukup mendekati tegangan referensi yang telah diatur, hal tersebut dapat disebabkan oleh kurangnya penguatan pada metode kontrol proportional integral, serta kemungkinan adanya drop voltage yang disebabkan oleh adanya beban sebesar 47 Ohm pada terminal keluaran inverter. Metode kontrol closed loop cascade menghasilkan tegangan keluaran inverter yang telah cukup mendekati tegangan referensi yang telah diatur.

Berdasarkan analisa yang telah dijelaskan, metode kontrol closed loop cascade merupakan metode kontrol yang cukup baik apabila digunakan pada perancangan inverter dengan feedback tegangan, karena selain memberikan feedback pada tegangan metode tersebut juga memberikan feedback pada arus keluaran inverter dengan penguatan proportional resonant supaya dihasilkan tegangan keluaran inverter yang dapat mencapai tegangan referensi.

\section{Kesimpulan}

Inverter satu fasa SPWM dengan feedback tegangan menggunakan metode kontrol proportional integral telah berhasil direalisasikan. Metode kontrol Proportional Integral telah dapat diimplementasikan pada inverter satu fasa SPWM sebagai metode kontrol feedback tegangan. Metode kontrol proportional integral yang digunakan sebagai penguatan tegangan keluaran inverter, kurang cukup optimal untuk mencapai tegangan referensi. Kurang optimalnya tegangan keluaran inverter untuk mencapai tegangan referensi tersebut dapat disebabkan oleh drop voltage. Drop voltage disebabkan oleh adanya beban sebesar $47 \mathrm{Ohm}$ pada terminal keluaran inverter serta kurangnya penguatan pada metode kontrol proportional integral.

\section{Referensi}

[1]. Zhang. Ningyun, "A Systematic Method for Designing a PR Controller and Active Damping of the LCL Filter for Single-Phase Grid-Connected PV Inverters", Energies, vol.7, pp. 3934-3954, 2014.

[2]. S. Yuvarajan and H. L. Chiou, "A Novel Sine PWM Scheme Using Waveform Generators," IEEE Trans. Ind. Electron., vol. 41, no. 3, pp. 372-376, 1994.

[3]. S. W. Smith, Digital signal processing, 2nd ed. San Diego, California: California Technical Publishing, 1999.

[4]. M. T. Inc., DSPIC30F4011/12 Data Sheet 16-Bit Digital Signal Controllers. 2010. 
[5]. Y. Nakata, K. Fujiwara, M. Yoshida, J. Itoh and Y. Okazaki, "Output voltage control for PWM inverter with electric double layer capacitor as DC power supply," The 2010 International Power Electronics Conference ECCE ASIA -, Sapporo, 2010, pp. 3099-3104.

[6]. T. L. Skvarenina, The power electronics handbook. New York: CRC Press LLC, 2002.

[7]. Daniel W Hart, Power Electronics, 2nd ed. New York: McGraw-Hill, 2011.

[8]. M. H. Rashid, POWER ELECTRONICS Academic Press Series in Engineering, 2001.

[9]. D. A. K. S. Anjana Thakur, "An Overview of Different PWM Techniques to Reduce Total Harmonic Distortion of Output in," Int. J. Recent Res. Electr. Electron. Eng., vol. 3, no. 2, pp. 65-69, 2016.

[10]. M. Tecnology Inc., "dsPIC30F Family Reference Manual," pp. 15-44, 2006.

[11]. Sardiyanto, "Pembuatan Modul Inverter 3 Fasa Sinusoidal Pulse Width Modulation Sebagai Pengaturan Kecepatan Motor Induksi 3 Fasa Terhubung Segitiga 220 Volt," Transient, 2003

[12]. Allegro, "Fully Integrated, Hall Effect-Based Linear Current Sensor IC with $2.1 \mathrm{kVRMS}$ Isolation and a Low-Resistance Current Conductor", no. 16, pp. 1-16, 2017.

[13]. O. T. Way, "2.7 V to $5.5 \mathrm{~V}$, Parallel Input Dual Voltage Output 8-Bit DAC," pp. 1-8, 1997.

[14]. I. Electronics, "DAC-08 Digital to Analog Converter," pp. 7-8, 2005.
[15]. Ye. Tao, Dai. Ning-Yi, Lam. Chi-Seng, Wong. ManChung, Guerrero. Josep M., "Analysis, Design and Implementation of a Quasi-Proportional-Resonant Controller for a Multifunctional Capacitive-Coupling Grid-Connected Inverter". IEEE Transaction on Industry Applications. 2016

[16]. N. Semiconductor, Datasheet LM78XX Series Voltage Regulators, no. February. 1995, pp. 1-6.

[17]. TOSHIBA, "Photocoupler GaAlAs Ired \& Photo-IC TLP250," vol. 5, pp. 1-8, 2004.

[18]. Intersil, "Mur1540, mur1560, rurp1540, rurp1560.," no. 2778, pp. 1-4, 2000.

[19]. I. Rectifier, "IRFP460" vol. PD-9.512B , pp. 10251030.

[20]. M. Gopal, "Digital Control and State Variable Methods", 2nd ed. Tata McGraw-Hill, 2003.

[21]. Abdurrahman Muhammad Hanif, Setiawan Iwan, Handoko Susatyo, "Desain dan Implementasi Synchronous Reference Frame-Phase Locked Loop (SRF-PLL) untuk Tegangan Satu Fase Menggunakan dsPIC30f4011," TRANSIENT, vol. 7, no. 1, pp. 146151,2018

[22]. Darjat, M. Syahadi, and I. Setiawan, "Aplikasi kontrol Proposional Integral Berbasis Mikrokontroler Atmega8535 untuk Pengaturan suhu Pada Alat Pengering Kertas," Seminar Ilmiah Nasional Komputer dan Sistem Intelijen KOMMIT 2008, pp. 20-21, 2008. 